\title{
Calcium, Vitamin D and Cardiovascular Disease
}

\author{
Idris Guessous ${ }^{\mathrm{a}, \mathrm{b}}$ Murielle Bochud ${ }^{\mathrm{b}}$ Olivier Bonny ${ }^{\mathrm{c}}$ Michel Burnier ${ }^{\mathrm{c}}$ \\ a Unit of Population Epidemiology, Division of Primary Care Medicine, Department of Community Medicine, \\ Primary Care and Emergency Medicine, Geneva University Hospitals, Geneva, ${ }^{b}$ Community Prevention Unit, \\ University Institute of Social and Preventive Medicine (IUMSP), and ${ }^{\mathrm{C}}$ Department of Medicine, Service of \\ Nephrology, Centre Hospitalier Universitaire Vaudois (CHUV), Lausanne, Switzerland
}

\section{Key Words}

Calcium $\cdot$ Cardiovascular disease $\cdot$ Vitamin D

\begin{abstract}
The relationship between calcium and cardiovascular diseases (CVD) has been explored for a long time. Studies exploring the effect of calcium intake or calcium supplementation on cardiovascular risk suggest that systolic blood pressure increases under low calcium intake and decreases with calcium supplementation. A lower calcium intake has been associated with an increased risk of stroke. However, the impact of calcium supplementation on stroke risk remains unclear. Calcium supplementation may increase the risk of myocardial infarction. The relationship between vitamin $D$ and CVD has been explored more recently. Negative correlations between vitamin D levels and the risk of hypertension, myocardial infarction, and stroke have been reported in several observational studies. The effect of vitamin D supplementation on blood pressure is still unclear and no effect of vitamin $\mathrm{D}$ supplementation on coronary heart disease or stroke has been clearly demonstrated. There is a lack of randomized clinical trials primarily addressing the effect of these parameters on CVD. Therefore, the real impact of calcium and vitamin $D$ on cardiovascular outcomes remains to be documented by appropriate experimental data.
\end{abstract}

Copyright $\odot 2011$ S. Karger AG, Basel
(C) 2011 S. Karger AG, Basel

1420-4096/11/0346-0404\$38.00/0

Fax +41613061234 E-Mail karger@karger.ch www.karger.com
Accessible online at:

www.karger.com/kbr

\section{Introduction}

Molecular, animal and human studies have established that both calcium and vitamin D are associated with cardiovascular diseases (CVD). Due to the high prevalence of calcium supplementation and to the high prevalence of vitamin $\mathrm{D}$ deficiency in the general population, determination of the cardiovascular benefits and risks associated with calcium and vitamin D plasma levels or with calcium and vitamin D supplementation is a public health concern.

In this review, the actual evidence on the role of calcium and vitamin D on CVD are reviewed. We have limited the discussion on the epidemiological studies associating calcium and vitamin D with blood pressure (BP), coronary heart disease (CHD) and stroke. Evidence from randomized controlled trials of supplements is discussed first, followed by observational data on dietary intake, and serum levels, and finally, possible action mechanisms that might explain these findings are presented.

\section{Calcium and Cardiovascular Disease}

\section{Calcium and Blood Pressure}

Calcium Supplementation and Blood Pressure

More than 60 trials have evaluated the effect of calcium supplementation on BP. These trials have been summarized in six systematic reviews (table 1) [1-6] which have been recently reviewed [7]. 
Table 1. Reported dietary calcium intake, or calcium supplements, and BP in prospective studies

\begin{tabular}{|c|c|c|c|c|}
\hline Association & $\begin{array}{l}\text { Reference } \\
\text { (first author) }\end{array}$ & Method & Country and participants & Result $^{1}$ \\
\hline \multirow{6}{*}{$\begin{array}{l}\text { Calcium } \\
\text { supplementation } \\
\text { and change in BP }\end{array}$} & Cappuccio, 1989 [3] & Systematic review of RCTs & $\mathrm{NT}+\mathrm{HT}$ & $\begin{array}{l}\text { SBP (supine): }-0.13(-0.46,+0.19) \\
\text { DBP (supine): }+0.03(-0.17,+0.22)\end{array}$ \\
\hline & Bucher, 1996 [2] & Systematic review of RCTs & NT & $\begin{array}{l}\text { SBP: }-0.27(-1.80,+1.27) \\
\text { DBP: }-0.33(-1.56,+0.90)\end{array}$ \\
\hline & Allender, 1996 [1] & Systematic review of RCTs & NT & $\begin{array}{l}\text { SBP: }-0.53(-1.56,+0.49) \\
\text { DBP: }-0.28(-0.99,+0.42)\end{array}$ \\
\hline & Griffith, 1999 [5] & Systematic review of RCTs & $\mathrm{NT}+\mathrm{HT}$ & $\begin{array}{l}\text { SBP: }-1.44(-2.20,-0.68) \\
\text { DBP: }-0.84(-1.44,-0.24)\end{array}$ \\
\hline & Van Mierlo, 2006 [6] & Systematic review of RCTs & $\mathrm{NT}+\mathrm{HT}$ & $\begin{array}{l}\text { SBP: }-1.86(-2.91,-0.81) \\
\text { DBP: }-0.99(-1.61,-0.37)\end{array}$ \\
\hline & Dickinson, 2006 [4] & Systematic review of RCTs & HT & $\begin{array}{l}\text { SBP: }-2.53(-4.45,-0.60) \\
\text { DBP: }-0.81(-2.07,+0.44)\end{array}$ \\
\hline \multirow{6}{*}{$\begin{array}{l}\text { Calcium intake } \\
\text { and incidence } \\
\text { of hypertension } \\
\text { (observational } \\
\text { studies) }\end{array}$} & Ford, $1991[12]$ & Cohort study (not available) & USA, men + women, $\geq 25$ years & No association \\
\hline & Ascherio, $1992[10]$ & Cohort study, FFQ & USA, men + women, $40-75$ years & No association \\
\hline & Ascherio, 1996 [14] & Cohort study, FFQ & USA, women, $30-55$ years & No association \\
\hline & Dwyer, 1996 [11] & Cohort study, $24 \mathrm{~h}$ recall & USA, men + women, $<40$ years & Lower calcium intake $\rightarrow$ increased risk of HT \\
\hline & Alonso, 2005 [9] & Cohort study, FFQ & Spain, men + women, $20-90$ years & No association \\
\hline & Wang, 2008 [13] & Cohort study, FFQ & USA, women, $>45$ years & Lower calcium intake $\rightarrow$ increased risk of HT \\
\hline
\end{tabular}

$\mathrm{NT}=$ Normotensive people; $\mathrm{HT}=$ hypertensive people; $\mathrm{FFQ}=$ food frequency questionnaire; $\mathrm{RCT}=$ randomized controlled trial; $\mathrm{SBP}=$ systolic blood pressure; $\mathrm{DBP}=$ diastolic blood pressure.

The systematic reviews that reported on study heterogeneity found significant heterogeneity. For calcium supplementation, only results from systematic reviews are reported.

${ }^{1}$ For systematic reviews of RCTs, results are expressed as mean changes (95\% CI) between intervention group and control group.

Systematic reviews of trials in which analyses were performed on normotensive subjects found no effect of calcium supplementation on BP $[1,2]$. On the other hand, three $[1,2,4]$ out of the four systematic reviews [1-4] that analyzed the effect of calcium supplementation on BP in hypertensive patients reported significant effects. Calcium supplementation decreased systolic BP (SBP) by 2-4 mm Hg compared to placebo, but generally had no effect on diastolic BP (DBP). Only one systematic review found an effect of calcium supplementation on DBP $(-1.5$ $\mathrm{mm} \mathrm{Hg}$ ) [2].

All systematic reviews that combined subjects with and without hypertension and analyzed the effect of calcium supplementation on BP $[1-3,5,6]$ reported an effect of calcium supplementation on SBP $(-0.9$ to $-1.9 \mathrm{~mm} \mathrm{Hg})$, and two out of five found an effect on DBP as well $(-0.8$ to $-1.0 \mathrm{~mm} \mathrm{Hg}$ ) $[5,6]$.

These systematic reviews have shown that (i) calcium supplementation (1,000-1,500 mg/day) can reduce SBP, particularly among hypertensive subjects, (ii) the effect of calcium supplementation on DBP is inconsistent, and (iii) there is no evidence of a beneficial effect of calcium supplementation among normotensive subjects.
Limitations of these systematic reviews are those of the original trials. Trials were heterogeneous with respect to calcium dose (range 400-2,000 mg/day), eligibility criteria (such as age, normo/hypertensive status), and supplementation duration (range 1-10 months) [7].

\section{Calcium Intake and Blood Pressure}

International epidemiological comparisons as well as studies of migrants suggested that diet, and notably dairy product consumption, could determine BP [8]. Because calcium is one of the major nutrients of dairy products, it has been presented as a possible determinant of BP variability.

Five cohorts evaluated the association between calcium intake and the incidence of hypertension (table 1) [914]. Calcium intake was determined by either food frequency questionnaire (FFQ) $[9,10,13,14]$, or $24 \mathrm{~h}$ recall [11]. All studies included normotensive participants at baseline. Chung et al. [7] recently summarized the evidence emerging from these studies. There was no association between calcium intake and the risk of hypertension. 


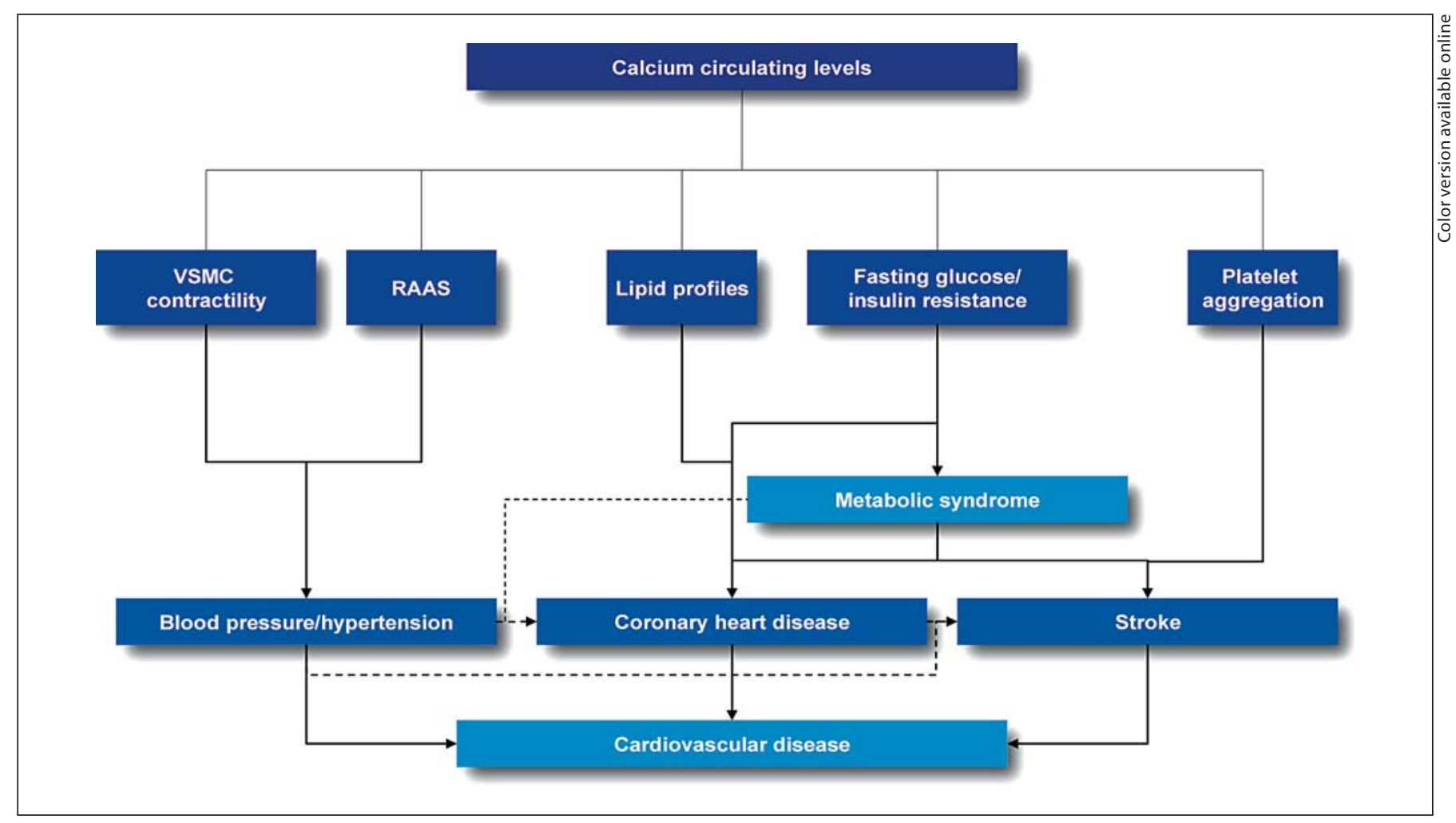

Fig. 1. Main hypothetical mechanism of actions of calcium circulating levels on cardiovascular disease (mechanisms related to parathormone and vitamin D are not displayed for the purpose of clarity, refer to the text for details). VSMC = Vascular smooth muscle cells; RAAS = renin-angiotensin-aldosterone system.

Two of the cohort studies restricted their analyses to $<40$-year-olds [11] and <50-year-olds [10]. Both studies found that lower calcium intake was associated with an increased risk of hypertension compared to higher calcium intake (relative risk (RR) 1.52 for $<500$ vs. $>1,100$ $\mathrm{mg} /$ day calcium intake, $\mathrm{p}<0.05$ [10]; RR 1.33 per 1-g/day increase of calcium intake, $\mathrm{p}<0.04$ [11]). These associations were not found in older adults. One study found higher rates of hypertension (RR 1.12, 95\% CI 1.05-1.20) among women consuming lower calcium per day $(<558$ $\mathrm{mg} /$ day) compared to those with higher consumption (>679 mg/day) [13]. Two other studies found no such associations in women $[12,14]$.

Overall, (i) the association of calcium intake with the risk of hypertension seems to be limited to young subjects and (ii) a gender modification effect is not consistently observed.

Limitations of these studies include reliance on selfreported hypertension (BP was measured by investigators in only one study [13]), as well as limitations associated with the use of FFQ or $24 \mathrm{~h}$ recall [15].

\section{Calcium Serum Levels and Blood Pressure}

In 1976, Bulpitt et al. [16] first reported an association between serum calcium levels and SBP in a general population. Since then, several studies have explored this relation and results are conflicting [17-27]. Overall, it appears that association, if any, of serum calcium levels with $\mathrm{BP}$ is limited to SBP. It also seems that the association is absent in subjects with normal renin activity [19]. Few of these studies measured ionized calcium, or used values corrected for blood $\mathrm{pH}$ and/or albumin levels, or adjusted for potential confounders such as PTH and vitamin D (see section Vitamin D and Blood Pressure).

\section{Possible Action Mechanisms (fig. 1)}

The relationship of calcium metabolism with $\mathrm{BP}$ is supported by biological observations [28]. Calcium controls vascular smooth muscle cell (VSMC) contractility and thus modulates peripheral vascular resistances [2932]. Calcium ATPase (PMCA1 or ATP2B1), sodium/calcium exchanger and TRPC6, three proteins related to calcium transport, have been involved in the control of 
Table 2. Reported dietary calcium intake and CHD in prospective studies

\begin{tabular}{|c|c|c|c|c|}
\hline Association & Reference (first author) & Method & Country and participants & Result $^{1}$ \\
\hline \multirow{4}{*}{$\begin{array}{l}\text { Ca supplementation } \\
\text { and CHD (RCTs) }\end{array}$} & Prince, 2006 [42] & $\begin{array}{l}\text { RCT, calcium carbonate } 600 \mathrm{mg} \\
\text { twice daily or placebo, } 5 \text { years }\end{array}$ & Australia, women $>70$ years & Risk ratio: $1.12(0.77-11.64)$ \\
\hline & Hsia, $2007[41]$ & $\begin{array}{l}\text { RCT, calcium carbonate } 500 \mathrm{mg} \\
\text { with vitamin D } 200 \text { IU twice daily } \\
\text { or placebo, } 7 \text { years }\end{array}$ & USA, women, $50-79$ years & Risk ratio: $1.08(0.99-1.19)$ \\
\hline & Bolland, 2008 [39] & $\begin{array}{l}\text { RCT, } 1,000 \mathrm{mg} \text { of citrate calcium or } \\
\text { placebo daily, } 5 \text { years }\end{array}$ & $\begin{array}{l}\text { New Zealand, postmenopausal } \\
\text { women, } \geq 55 \text { years }\end{array}$ & Risk ratio: 2.12 (1.01-14.47) \\
\hline & Bolland, 2010 [43] & Systematic review of RCTs & $\begin{array}{l}\text { Includes unpublished } \\
\text { data provided by authors }\end{array}$ & Risk ratio: 1.31 (1.02-1.67) \\
\hline \multirow{6}{*}{$\begin{array}{l}\text { Calcium intake } \\
\text { and incidence } \\
\text { of CHD } \\
\text { (observational } \\
\text { studies) }\end{array}$} & Van der Vijver, 1992 [49] & Cohort study, FFQ & $\begin{array}{l}\text { The Netherlands, men + women } \\
40-65 \text { years }\end{array}$ & No association \\
\hline & Bostick, 1999 [45] & Cohort study, FFQ & USA, women, 55-69 years & $\begin{array}{l}\text { Higher calcium intake } \rightarrow \text { lower } \\
\text { ischemic heart disease mortality }\end{array}$ \\
\hline & Al-Delaimy, 2003 [44] & Cohort study, FFQ & USA, men, $40-75$ years & No association \\
\hline & Marniemi, 2005 [46] & $\begin{array}{l}\text { Cohort study, dietary history } \\
\text { interviews }\end{array}$ & $\begin{array}{l}\text { Finland, men + women, } \\
65-99 \text { years }\end{array}$ & No association \\
\hline & Umesawa, 2006 [47] & Cohort study, FFQ & Japan, men, $40-79$ years & No association \\
\hline & Umesawa, 2008 [48] & Cohort study, FFQ & $\begin{array}{l}\text { Japan, men + women, } \\
40-59 \text { years }\end{array}$ & No association \\
\hline
\end{tabular}

$\mathrm{RCT}=$ Randomized controlled trial; FFQ = food frequency questionnaire; $\mathrm{CHD}=$ coronary heart disease.

${ }^{1}$ For RCTs, results are expressed as risk ratio (95\% CI) of CHD comparing the intervention group to the control group.

${ }^{2}$ None of these studies have been primarily designed to assess the relationship between calcium supplementation and CHD.

VSMC contractility $[33,34]$. PMCA1 has been associated with hypertension in one genome-wide association study [35]. Extracellular ionized calcium inhibits renin secretion by interacting with the calcium-sensing receptor expressed in the juxtaglomerulus apparatus [36-38].

\section{Calcium and Coronary Heart Disease}

Calcium Supplementation and Coronary Heart

Disease

No randomized control trial (RCT) has yet been primarily designed to assess the effect of calcium supplementation on CHD. Four trials [39-42] are secondary analyses of RCTs primarily designed to assess the effect of calcium supplementation on bone density and fracture in postmenopausal women (table 2).

The most recent RCT of calcium supplementation reported an increased risk of myocardial infarction (MI). Compared to the placebo group, postmenopausal women randomized to receive $1,000 \mathrm{mg}$ /day of calcium for 5 years had a twofold increased risk of MI (RR 2.12, 95\% CI 1.01-4.47) [39].

While this result contrasts with the findings reported in two previously published RCTs (Women Health Initiative [41] and Prince et al. [42]), increased risks, though not significant, were actually also reported in these two
RCTs (hazard ratio (HR) 1.08, 95\% CI 0.99-1.19 [41] and HR 1.12, 95\% CI 0.77-1.64 [42]). A recent meta-analysis of trials reported an increased risk of MI associated with calcium supplements (without vitamin D supplement) (HR 1.31, 95\% CI 1.02-1.67) [43].

Taken together, no definitive conclusion can be drawn from these secondary analyses, but at least two questions can be raised: (1) Did the supplementation of vitamin D together with calcium in RCTs blunt a significant increase in CHD events associated with calcium supplementation? A small increase in CHD events has been reported in the group supplemented with calcium and vitamin $\mathrm{D}$ versus the group receiving only placebo (and no calcium) in the Women Health Initiative study. (2) By which mechanism, if any, would calcium supplementation increase the risk of CHD? In the two RCTs that assessed the impact of supplementations on the lipid profile, calcium alone and calcium plus vitamin $\mathrm{D}$ were associated with beneficial trends in levels of HDL cholesterol and LDL cholesterol; unfavorable changes in lipids are unlikely to explain the increased risk. The effects of supplementation on BP (SBP and DBP) might have played a role. After a 5-year follow-up, Bolland et al. [43] reported no difference in SBP or DBP between groups, while Hsia et al. [41] reported, after a 2-year fol- 
low-up, a significant increase in both SBP $(+0.4 \%)$ and DBP $(+0.4 \%)$ in the calcium/vitamin D group compared to the placebo group. Whether such small changes in $\mathrm{BP}$ may have contributed to the increased risk is questionable. Therefore, these questions remain to be answered.

Notwithstanding the limitations of both observational and experimental studies, one could reasonably conclude that there is no strong evidence of a benefit of calcium supplementation with respect to CHD. Evidence of increased risk of MI associated with calcium supplementation has recently been reported [43] and deserves to be further investigated.

\section{Calcium Intake and Coronary Heart Disease}

The association between calcium intake and CHD (fatal and nonfatal MI) has been reported in six observational studies (table 2) [44-49].

With the exception of the Iowa Women Health Study, no observational studies reported an association between calcium intake and CHD. In the Iowa Women Health Study, the investigators reported a higher risk of $\mathrm{CHD}$ death (RR 1.58, 95\% CI 1.02-2.50) in white women aged $55-69$ years with low calcium intake ( $<696 \mathrm{mg} /$ day) compared to those with high calcium intake $(>1,425 \mathrm{mg} /$ day) [45].

\section{Calcium Levels and Coronary Heart Disease}

Elevated serum calcium levels have been associated with increased risk of CVD. In 1987, Palmer et al. [50] reported a lower survival rate among persons with hypercalcemia (defined as an albumin-corrected serum calcium $>2.60 \mathrm{mmol} / \mathrm{l}$ ) compared to normocalcemic age- and sex-matched controls. In a large population-based study, increased serum calcium was associated with increased mortality in men aged less than 50 years, which was mainly attributable to CVD [51]. In another study, serum calcium was associated with the incidence of acute $\mathrm{MI}$ in Swedish men (HR 2.33, 95\% CI 1.21-4.51) [52]. Total serum calcium levels were measured in 27,158 men and women (25-97 years) in the Tromsø Study (Norway) during 1994 and 1995. In all age groups, serum calcium levels were a predictor of MI in men (OR 1.2 per $0.1 \mathrm{mmol} / \mathrm{l}$ increase in serum calcium). In women, no significant trend was seen [20].

\section{Possible Action Mechanisms (fig. 1)}

Putative mechanisms of actions encompass effects of calcium on lipid profile, on fasting glucose levels, on platelet aggregation and on phosphate levels. Most studies, however, pointed to the beneficial effect of calcium intake on $\mathrm{BP}$ as the main putative mechanism of action for its protective effect on CHD [53].

Calcium may bind bile acids in the lumen of the intestine and increase their excretion. This may lower blood cholesterol levels and hence reduce the risk of CHD [45]. A reduction of serum total cholesterol has been reported in hypercholesterolemic subjects given $1 \mathrm{~g}$ of calcium for 8 weeks $[54,55]$. More recently, it has been shown that calcium supplementation with $1 \mathrm{~g} /$ day of calcium for 1 year increased HDL cholesterol and decreased LDL cholesterol levels compared to placebo $[56,57]$. Serum calcium concentrations have been associated with impaired glucose tolerance [58] and with markers of insulin resistance $[52,58,59]$.

Overall, calcium has been associated with deleterious effects on lipid profile and glucose tolerance, suggesting a possible link with the metabolic syndrome.

At last, platelet aggregation has been shown to be inversely related to calcium intake $[60,61]$. The precise mechanism is, however, not known. Calcium also binds to phosphate in the intestinal lumen and thus contributes to lower plasma phosphate levels. Low phosphate levels may be protective for CVD $[62,63]$.

Another emerging mechanism linking calcium to $\mathrm{CHD}$ is the presence of calcium in atherosclerotic lesions, and the reported value of coronary artery calcium (CAC) to predict CHD events [64]. While the clinical utility of CAC scoring, usually calculated using computed tomography, remains controversial $[64,65]$, a legitimate question is whether calcium supplementation can raise the level of CAC, and thus the risk of CVD events. A recent analysis of the Women's Health Initiative-Coronary Artery Calcium Study suggested that moderate $(\sim 1,000 \mathrm{mg} /$ day $)$ calcium supplementation does not raise CAC levels, at least when combined with 400 IU of vitamin $\mathrm{D}_{3}$ [66]. It remains, however, uncertain whether higher or lower doses of calcium, or different ratios of calcium and vitamin $\mathrm{D}$, would modify the level of CAC [66].

\section{Calcium and Stroke}

Calcium Supplementation and Stroke

A recent meta-analysis, which included unpublished data provided by authors, reported no association between calcium supplements and the risk of stroke (table 3) [43]. A well-designed RCT could confirm or refute a beneficial effect of calcium supplementaion on stroke prevention. However, the trial, if any, should monitor very closely the effect of calcium supplementation on $\mathrm{CHD}$. Given the recent debate regarding the safety of cal- 
Table 3. Reported dietary calcium intake and stroke in prospective studies

\begin{tabular}{|c|c|c|c|c|}
\hline Association & Reference (first author) & Method & Country and participants & Result \\
\hline $\begin{array}{l}\text { Calcium supplementation } \\
\text { and stroke (RCTs) }\end{array}$ & Bolland, 2010 [43] & Systematic review of RCTs & $\begin{array}{l}\text { Includes unpublished data provided } \\
\text { by authors }\end{array}$ & Risk ratio: $1.20(0.96-1.50)$ \\
\hline \multirow{8}{*}{$\begin{array}{l}\text { Calcium intake and } \\
\text { incidence of stroke } \\
\text { (observational studies) }\end{array}$} & Ross, $1997[70]$ & Cohort study, FFQ & China, men, $45-64$ years & No association \\
\hline & Ascherio, 1998 [68] & Cohort study, FFQ & USA, men, $40-75$ years & No association \\
\hline & Iso, 1999 [69] & Cohort study, FFQ & USA, women, $32-57$ years & No association \\
\hline & Marniemi, 2005 [46] & $\begin{array}{l}\text { Cohort study, } \\
\text { dietary history interviews }\end{array}$ & Finland, men + women, $65-99$ years & No association \\
\hline & Umesawa, 2006 [47] & Cohort study, FFQ & Japan, men + women, $40-79$ years & No association \\
\hline & Larsson, 2008 [53] & Cohort study, FFQ & Finland, men, $50-69$ years & No association \\
\hline & Umesawa, 2008 [48] & Cohort study, FFQ & Japan, men + women, $40-59$ years & $\begin{array}{l}\text { Higher calcium intake } \rightarrow \\
\text { decreased risk of stroke }\end{array}$ \\
\hline & Weng, $2008[71]$ & Cohort study, FFQ & Taiwan, men + women, $>40$ years & $\begin{array}{l}\text { Higher calcium intake } \rightarrow \\
\text { decreased risk of stroke }\end{array}$ \\
\hline
\end{tabular}

$\mathrm{RCT}=$ Randomized controlled trial; $\mathrm{FFQ}=$ food frequency questionnaire.

cium supplementation [67], it is not clear how acceptable such a trial would be from an ethical point of view.

\section{Calcium Intake and Stroke}

Eight observational studies compared the risk of stroke or stroke death based on calcium intake in humans [46-48, 53, 68-71]; half of them were performed in Asian populations $[47,48,70,71]$ (table 3). Two studies, both performed in Asia, reported an association between calcium intake and risk of stroke, a higher calcium intake decreasing the risk of stroke. For example, compared to subjects with a median calcium intake of $233 \mathrm{mg} /$ day, subjects with median calcium intake of 439,603 , and $753 \mathrm{mg} /$ day had a 21 , 22 , and $29 \%$, respectively reduced risk of stroke [48]. None of the studies performed in North American/European populations and none of the studies that used stroke death as an outcome actually found any association with calcium intake. A possible explanation for the different results observed between populations is the lower (almost 50\%) average calcium intake reported in Asian populations compared to North American/European populations.

\section{Calcium Levels and Stroke}

While the role of serum calcium levels has been investigated as a prognostic factor after ischemic stroke [72, 73], we found no large population-based information on the association of calcium levels with stroke.

Possible Action Mechanisms (fig. 1)

Some animal experiments have suggested a protective effect of a high calcium intake on stroke [74]. Action mechanisms are generally thought to be related to the hypotensive and antiplatelet aggregation properties of calcium.

\section{Vitamin D and Cardiovascular Disease}

\section{Vitamin D and Blood Pressure}

Vitamin D Supplementation and Blood Pressure

Three RCTs assessed the efficacy of vitamin D supplementation on BP [75-77] (table 4). Compared with calcium alone (1,200 mg/day), vitamin D (800 IU/day) and calcium $(1,200 \mathrm{mg} /$ day $)$ supplements resulted in $9.3 \%$ decreased SBP $(\mathrm{p}=0.02)$ in a 8 -week trial including 148 women (mean age 74 years) with a $25(\mathrm{OH}) \mathrm{D}$ level $<50$ $\mathrm{nmol} / \mathrm{l}$ [75]. One study investigated the impact of three times weekly full-body UVB irradiation, and thus indirectly vitamin $\mathrm{D}$ production, on ambulatory $\mathrm{BP}$ and reported a $162 \%$ rise in plasma concentrations of $25(\mathrm{OH}) \mathrm{D}$ and a significant effect of UVB to lower systemic BP [78].

Overall, there are several studies but not enough robust evidence to conclude whether vitamin D supplementation is beneficial for, or detrimental to, BP. In the context of large food fortification of vitamin $\mathrm{D}$, the possible increased risk of arterial stiffness and hypertension related to vitamin $\mathrm{D}$ needs to be further investigated.

Vitamin D Intake and Blood Pressure

In 2008, Wang et al. [13] investigated the associations of vitamin D intake with the incidence of hypertension in a 10 -year prospective cohort of 28,886 US women aged 
Table 4. Vitamin D levels, or vitamin D supplements, and BP in prospective studies

\begin{tabular}{|c|c|c|c|c|}
\hline Association & $\begin{array}{l}\text { Reference } \\
\text { (first author) }\end{array}$ & Method & Country and participants & Result $^{1}$ \\
\hline \multirow[t]{3}{*}{$\begin{array}{l}\text { Vitamin D } \\
\text { supplementation } \\
\text { and BP (RCTs) }\end{array}$} & Pfeifer, 2001 [75] & $\begin{array}{l}\text { RCT, } 1,200 \mathrm{mg} \text { calcium + } 800 \mathrm{IU} \\
\text { vitamin } \mathrm{D}_{3} \text { daily or } 1,200 \mathrm{mg} \\
\text { calcium daily, } 8 \text { weeks }\end{array}$ & $\begin{array}{l}\text { Germany, women with } 25(\mathrm{OH}) \mathrm{D} \\
<50 \mathrm{ng} / \mathrm{ml}, 70-86 \text { years, NT+HT }\end{array}$ & $\begin{array}{l}\text { SBP: }-7.4(-13.2,-1.2) \\
\text { DBP: }-0.3(-0.7,-0.1)\end{array}$ \\
\hline & Scragg, 1995 [77] & $\begin{array}{l}\text { RCT, } 100,000 \text { IU vitamin } \mathrm{D}_{3} \text { or } \\
\text { placebo, once }\end{array}$ & $\begin{array}{l}\text { UK, men + women, } 63-76 \text { years, } \\
\text { NT+HT }\end{array}$ & $\begin{array}{l}\text { SBP: } 0(-4.0,+4.0) \\
\text { DBP: } 0(-3.0,+3.0)\end{array}$ \\
\hline & Nagpal, 2009 [76] & $\begin{array}{l}\text { RCT, } 120,000 \mathrm{IU} \text { vitamin } \mathrm{D}_{3} \text { or } \\
\text { placebo, every } 2 \text { weeks during } 6 \text { weeks }\end{array}$ & India, men, $\geq 35$ years & $\begin{array}{l}\text { SBP: }+3.95(-0.02,+8.00) \\
\text { DBP: }+1.69(-1.5,+4.9)\end{array}$ \\
\hline \multirow{4}{*}{$\begin{array}{l}\text { Vitamin D levels } \\
\text { and incidence of } \\
\text { hypertension } \\
\text { (observational } \\
\text { studies) }\end{array}$} & Forman, 2007 [98] & $\begin{array}{l}\text { Cohort study, } 25(\mathrm{OH})_{2} \mathrm{D} \\
\text { radioimmunoassay }\end{array}$ & USA, men + women, $40-75$ years & $\begin{array}{l}\text { Lower vitamin D levels } \rightarrow \\
\text { increased risk of HT }\end{array}$ \\
\hline & Forman, 2008 [97] & $\begin{array}{l}\text { Cohort study, } 25(\mathrm{OH})_{2} \mathrm{D} \text { enzyme } \\
\text { immunoassay }\end{array}$ & USA, women, $40-46$ years & $\begin{array}{l}\text { Lower vitamin D levels } \rightarrow \\
\text { increased risk of HT }\end{array}$ \\
\hline & Forouhi, 2008 [95] & $\begin{array}{l}\text { Cohort study, } 25(\mathrm{OH})_{2} \mathrm{D} \\
\text { radioimmunoassay }\end{array}$ & UK, men + women, $40-69$ years & $\begin{array}{l}\text { No association with change in } \\
\text { SBP or DBP }\end{array}$ \\
\hline & Jorde, 2010 [98] & $\begin{array}{l}\text { Cohort study, } 25(\mathrm{OH})_{2} \mathrm{D} \\
\text { radioimmunoassay }\end{array}$ & $\begin{array}{l}\text { Norway, men + women, } \\
50-74 \text { years }\end{array}$ & $\begin{array}{l}\text { No association with change in SBP or } \\
\text { DBP. No association with risk of HT }\end{array}$ \\
\hline
\end{tabular}

$\geq 45$ years. Vitamin D intake was assessed from FFQ. The risk of hypertension decreased in the higher quintiles of dietary vitamin $\mathrm{D}$, even after adjustment for dietary calcium intake. This observation was reported for vitamin $\mathrm{D}$ intake from diet, not from supplements. Associations of vitamin $\mathrm{D}$ intake with $\mathrm{BP}$ were also suggested in two previous smaller studies $[79,80]$.

\section{5(OH)D Levels and Blood Pressure}

Association between 25(OH)D levels and BP has been assessed in several cross-sectional studies. Large crosssectional studies show a significant inverse association between 25(OH)D levels and BP. In one of the largest studies, the NHANES III (12,644 participants aged $>20$ years), SBP was lower in the highest $25(\mathrm{OH}) \mathrm{D}$ quintile compared to the lowest quintile $(-3.0 \mathrm{~mm} \mathrm{Hg}$, standard error 0.7) [81]. Associations were also reported in two large European studies [82, 83]. Nine studies reported no significant associations [84-90] and four reported a positive correlation (higher level of $25(\mathrm{OH}) \mathrm{D}$ associated with higher prevalence of hypertension [91-94]).

The number of prospective studies examining $25(\mathrm{OH}) \mathrm{D}$ levels and the incidence of hypertension or change in BP are limited and results are inconsistent [9598] (table 4). Most studies were small, had suboptimal BP measurement (e.g., single measure of BP), or did not control for potential confounders such as PTH [99].
Possible Action Mechanisms (fig. 2)

Molecular evidence revealed actions of $1,25(\mathrm{OH})_{2} \mathrm{D}$ on mechanisms related to kidney function and BP. These mechanisms include a direct inhibition of $1,25(\mathrm{OH})_{2} \mathrm{D}$ on the renin-angiotensin system and nuclear factor- $\kappa \mathrm{B}$ (NF$\kappa B)$ pathway. The vitamin D receptor (VDR) is expressed in the juxtaglomerular apparatus and modulates renin synthesis. Mice in which VDR was abolished are hyperreninemic and present high BP and cardiac hypertrophy [100]. By contrast, when VDR was overexpressed in the mouse juxtaglomerular apparatus, hyporeninemia was noted [101].

NF- $\kappa \mathrm{B}$ is a family of transcription factors that functions as a master regulator of immune response [102]. It regulates a wide range of genes involved in inflammation, proliferation and fibrogenesis and is known to have a key role in kidney disease [103]. Both the renin-angiotensin system and the NF- $\kappa \mathrm{B}$ promote the production of profibrotic and pro-inflammatory factors, increase oxidative stress, and damage podocytes.

In addition, vitamin $\mathrm{D}$ can regulate $\mathrm{BP}$ through the prevention of secondary hyperparathyroidism [104]. Vitamin $\mathrm{D}$ seems to have a direct effect on vascular cells and endothelial function as well $[105,106]$. Vitamin D could potentially contribute to arterial stiffening and hypertension. Richart et al. [107] proposed mechanisms of renal versus extrarenal activation of vitamin $\mathrm{D}$ in relation to atherosclerosis, arterial stiffening, and hypertension. 


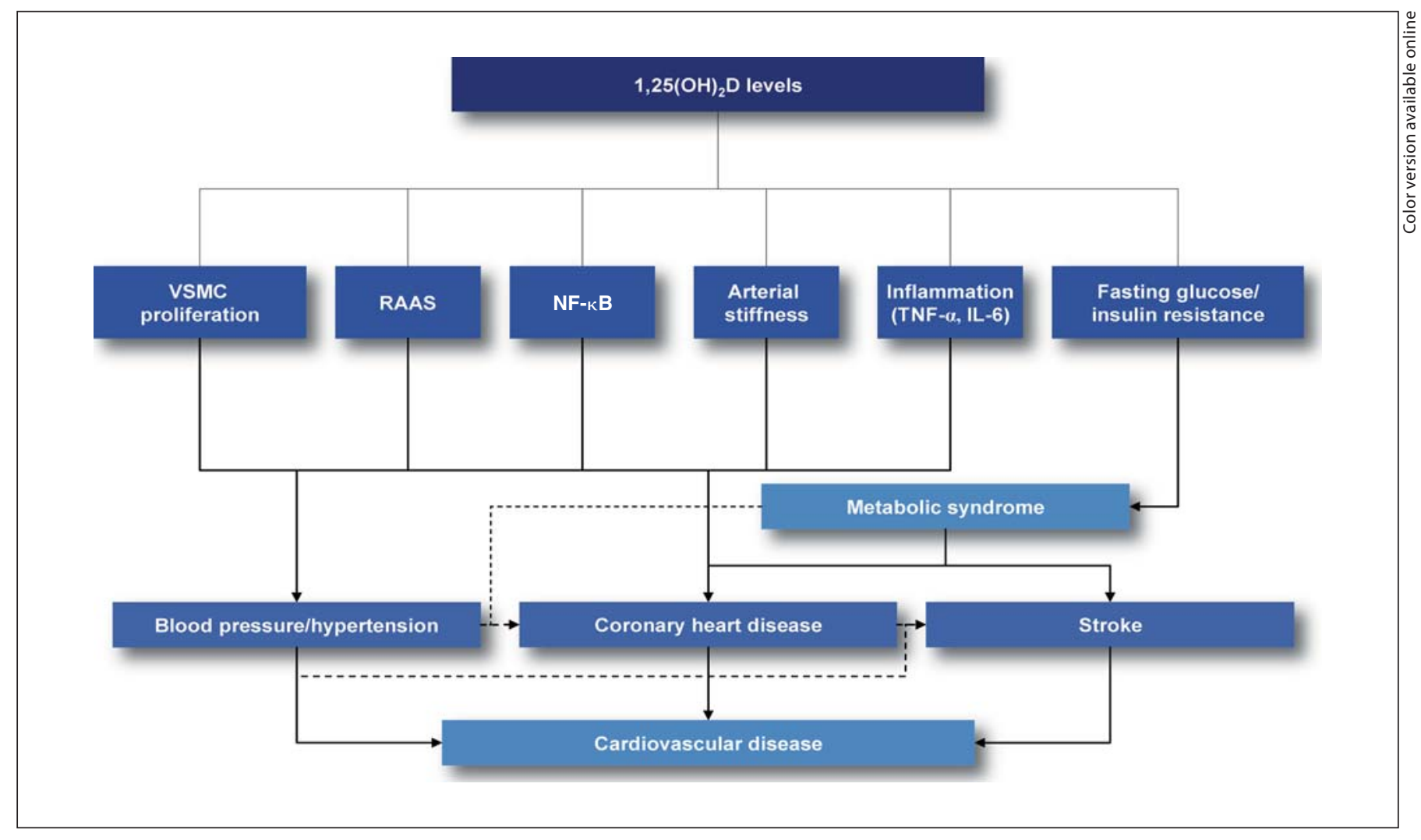

Fig. 2. Main hypothetical mechanism of actions of vitamin D on cardiovascular disease (mechanisms related to parathormone and calcium are not displayed for the purpose of clarity, refer to the text for details). VSMC = Vascular smooth muscle cells; RAAS = renin-angiotensin-aldosterone system; NF- $\kappa$ B = nuclear factor- $\kappa$ B; TNF- $\alpha=$ tumor necrosis factor- $\alpha$; IL- 6 = interleukin- 6 .

Macrophages in atherosclerotic lesions can locally activate $25(\mathrm{OH}) \mathrm{D}$ to calcitriol, which could act as a vasoactive and pro-oxidative substance on VSMCs.

\section{Vitamin D and Coronary Heart Disease}

There is an increasing body of literature linking vitamin D to CHD. Ecological studies have reported an inverse relationship between ischemic heart disease and the amount of hours of sunlight [108], as well as the strong seasonal pattern of CHD mortality consistent with the vitamin D blood level seasonal pattern [109].

\section{Vitamin D Supplementation and Coronary Heart}

Disease

No RCT has been conducted to evaluate the effect of vitamin D supplementation (with or without calcium) on $\mathrm{CHD}$ as primary outcome. One RCT, primarily designed to determine the effect of vitamin D supplementation on the risk of fractures, reported data on CHD. The investi- gators randomized 1,686 elderly men and women to vitamin D 100,000 IU three times a year or placebo for 5 years. They reported no effect of vitamin D supplementation on ischemic heart disease. There was a tendency for fewer events among the interventions group (16.7 vs. 17.4\%) [110] (table 5). Another RCT, which randomized postmenopausal women to vitamin D (400 IU/day) and calcium $(1,000 \mathrm{mg} /$ day) or placebo for an average of 7 years, reported no difference in cardiovascular mortality [111].

Specifically designed RCT(s) will be needed to determine whether vitamin $\mathrm{D}$ supplementation can reduce CHD events and mortality.

Vitamin D Intake and Coronary Heart Disease Only one study has assessed associations of vitamin D intake with CHD. In 1999, Bostick et al. [45] investigated whether vitamin $\mathrm{D}$ intake protected against ischemic heart disease mortality. In this prospective study of more 
Table 5. Vitamin D levels, or vitamin D supplements, and CHD in prospective studies

\begin{tabular}{|c|c|c|c|c|}
\hline Association & Reference (first author) & Method & Country and participants & Result $^{1}$ \\
\hline $\begin{array}{l}\text { Vitamin D supplementation } \\
\text { and CHD (RCTs) }\end{array}$ & Trivedi, 2003 [110] & $\begin{array}{l}\mathrm{RCT}, 100,000 \mathrm{IU} \text { oral vitamin } \mathrm{D}_{3} \text { or } \\
\text { placebo every } 4 \text { months over } 5 \text { years }\end{array}$ & $\begin{array}{l}\text { UK, men + women, } \\
65-85 \text { years }\end{array}$ & Risk ratio: $0.94(0.77-1.15)$ \\
\hline \multirow{2}{*}{$\begin{array}{l}\text { Vitamin D levels and } \\
\text { incidence of CHD } \\
\text { (observational studies) }\end{array}$} & Marniemi, 2005 [46] & $\begin{array}{l}\text { Cohort study, } 25(\mathrm{OH}) \mathrm{D} \text { and } \\
1,25(\mathrm{OH})_{2} \mathrm{D} \text { radioimmunoassay }\end{array}$ & $\begin{array}{l}\text { Finland, men and women, } \\
66-99 \text { years }\end{array}$ & No association \\
\hline & Giovannucci, 2008 [119] & $\begin{array}{l}\text { Cohort study, } 25(\mathrm{OH}) \mathrm{D} \\
\text { radioimmunoassay }\end{array}$ & USA, men, $40-75$ years & $\begin{array}{l}\text { Lower vitamin D levels } \rightarrow \\
\text { increased risk of MI }\end{array}$ \\
\hline
\end{tabular}

${ }^{1}$ For RCTs, results are expressed as risk ratio (95\% CI) of CHD comparing the intervention group to the control group.

${ }^{2}$ None of these studies have been primarily designed to assess the relationship between vitamin supplementation and CHD.

than 30,000 postmenopausal women in the USA, the authors found no association between baseline vitamin D and ischemic heart disease mortality.

\section{5(OH)D Levels and Coronary Heart Disease}

At least eleven observational studies on vitamin $\mathrm{D}$ and CHD have been published (table 5). 25(OH)D was estimated using FFQ or measured in blood, generally by radioimmunoassay. Outcomes included angina or MI (nonfatal or fatal).

In four studies, no specific association of vitamin $\mathrm{D}$ with $\mathrm{CHD}$, on the one hand, and stroke, on the other, could be assessed separately, as they used composite outcome. Wang et al. [112] reported an increased risk of CVD (CHD and stroke combined) in individuals with $25(\mathrm{OH}) \mathrm{D}<15 \mathrm{ng} / \mathrm{ml}$ compared to those with higher 25(OH)D levels (HR 2.13, 95\% CI 1.30-3.48). This was evident in participants with hypertension only. Risk of CVD was also increased (about twofold) among subjects with lower 25(OH)D levels compared to higher levels in a German prospective study, even after adjustment for hypertension [113]. Using NHANES III (1988-1994) data, Kendrick et al. [114] indicated an association of 25(OH)D deficiency with prevalent CVD, but Melamed et al. [115] previously analyzed these data and found no association between 25(OH)D levels and risk of CVD mortality.

At least five studies reported CHD outcome specifically (table 5). One study tested the association of low 25(OH)D levels with prevalent CHD using more recent NHANES (2001-2004) data. After full adjustment, no association was found [116]. No association between vitamin D intake or vitamin D and the risk of MI were found in a Finnish population-based study of elderly subjects [46]. A case-control study in South India reported an increased odds of ischemic heart disease among patients with $25(\mathrm{OH})$ D levels $>89 \mathrm{ng} / \mathrm{ml}$ compared to those with lower levels (odds ratio 3.18, 95\% CI 1.31-7.73) [117]. This result contrasts with a previous case-control study performed in the USA [118]. While the authors acknowledged that even strong and prolonged UVB light cannot be toxic, they suggested that the high intake of foods rich in vitamin $\mathrm{D}$, such as the one observed in India, could be deleterious. Opposite findings were reported in a nested case-control study of the Health Professional Follow-Up Study (HPFS). Compared to men with vitamin $\mathrm{D} \geq 30$ $\mathrm{ng} / \mathrm{ml}$, men with vitamin D deficiency $(\leq 15 \mathrm{ng} / \mathrm{ml})$ were at increased risk of MI (RR 2.09, 95\% CI 1.24-3.54) [119].

Overall, independent association between vitamin D and prevalence or risk of CHD is not evident from observational studies conducted so far. A case-control study in India found a deleterious effect of vitamin $\mathrm{D}$ on ischemic heart disease. While most other studies suggested that vitamin $\mathrm{D}$ had no effect or a tendency to protect from CHD or CVD, definitive conclusion based on robust evidence is currently impossible to draw.

Possible Action Mechanisms (fig. 2)

Different mechanisms have been proposed on how vitamin D could be associated with CHD [120]. Some mechanisms are indirect. Vitamin D could be related to CAD via its effect on BP, on glycemic control or on PTH. Because an excess of PTH levels can by itself promote atherosclerosis [121], it is not clear how much of the effect of vitamin $\mathrm{D}$ on atherosclerosis is attributable to vitamin $\mathrm{D}$ deficiency or to PTH excess caused by vitamin D deficiency.

Other mechanisms are more directly related to atherosclerosis, cardiac tissues and vasculature. Animal studies highlighted the role of vitamin D on cardiomyocyte remodeling in response to injury and atherosclerosis, as well as on cardiac relaxation and contractility $[122,123]$. We previously discussed that the presence of 
Table 6. Vitamin D levels, or vitamin D supplementation, and stroke in prospective studies

\begin{tabular}{|c|c|c|c|c|}
\hline Association & $\begin{array}{l}\text { Reference } \\
\text { (first author) }\end{array}$ & Method & $\begin{array}{l}\text { Country and } \\
\text { participants }\end{array}$ & Result $^{1}$ \\
\hline $\begin{array}{l}\text { Vitamin D supplementation } \\
\text { and stroke (RCTs) }{ }^{2}\end{array}$ & Trivedi, 2003 [110] & $\begin{array}{l}\mathrm{RCT}, 100,000 \mathrm{IU} \text { oral vitamin } \mathrm{D}_{3} \text { or } \\
\text { placebo every } 4 \text { months over } 5 \text { years }\end{array}$ & $\begin{array}{l}\text { UK, men }+ \text { women, } \\
65-85 \text { years }\end{array}$ & Risk ratio: 1.02 (0.77-1.36) \\
\hline $\begin{array}{l}\text { Vitamin D levels and incidence } \\
\text { of stroke (observational studies) }\end{array}$ & Marniemi, 2005 [46] & $\begin{array}{l}\text { Cohort study, } 25(\mathrm{OH}) \mathrm{D} \text { and } \\
1,25(\mathrm{OH})_{2} \mathrm{D} \text { radioimmunoassay }\end{array}$ & $\begin{array}{l}\text { Finland, men + women, } \\
66-99 \text { years }\end{array}$ & $\begin{array}{l}\text { Higher levels of } 1,25(\mathrm{OH})_{2} \mathrm{D} \rightarrow \\
\text { decreased risk of stroke }\end{array}$ \\
\hline
\end{tabular}

calcium within coronary vasculature is associated with an increased risk of MI. Serum levels of vitamin D seem to be inversely associated with the extent of vascular calcifications in individuals at risk of ischemic heart disease $[120,124]$. Vitamin D could protect from atherosclerosis and vascular calcification by its direct effect on VSMCs; vitamin D creates an acute influx of calcium in VSMCs that might inhibit their proliferation $[120,125]$. Vitamin D could also be associated with CHD by downregulating proinflammatory cytokines (e.g., TNF- $\alpha$, IL-6) and upregulating an anti-inflammatory cytokine (IL-10) [120].

Finally, there is great interest in the role of vitamin D on the susceptibility for type 2 diabetes and metabolic syndrome [125]. The effects of vitamin $\mathrm{D}$ on type 2 diabetes could be mediated by its role on pancreatic $\beta$-cell function, insulin resistance, or inflammation [126].

\section{Vitamin D and Stroke}

So far, few studies have explored whether vitamin D levels could be predictive for stroke. Possible action mechanisms include the protective role of vitamin $\mathrm{D}$ on hypertension and diabetes mellitus.

Vitamin D Supplementation and Stroke

Only one study assessed the impact of vitamin D on the incidence of stroke. In this study, Trivedi et al. [110] found no significant effects of vitamin $\mathrm{D}$ on the incidence of cerebrovascular events (table 6).

Vitamin D Intake and Stroke

In a health survey including around 760 elderly subjects, low intake of vitamin $\mathrm{D}$ as well as low $1,25(\mathrm{OH})_{2} \mathrm{D}$ levels were predictive of stroke [46] (table 6). Tertile cutoffs of vitamin $\mathrm{D}$ intake and $1,25(\mathrm{OH})_{2} \mathrm{D}$ levels were not provided, but compared to the lowest tertile, the risks of stroke were more than halved for elderly people in the middle and in the higher tertiles, for both vitamin $\mathrm{D}$ intake and $1,25(\mathrm{OH})_{2} \mathrm{D}$ levels [46].

\section{5(OH)D Levels and Stroke}

In a case-control study, hemiplegic patients with acute stroke showed reduced 25(OH)D levels compared to controls [127]. In a cohort of patients $(>3,000)$ referred to coronary angiography, low levels of $25(\mathrm{OH}) \mathrm{D}$ predicted fatal stroke (mean follow-up 7.7 years) [128].

\section{Conclusions}

This article reviews the associations between calcium and vitamin D with BP, CHD and stroke. Associations with other factors that also determine the risk of CVD have not been discussed. For example, chronic kidney failure (CKD) is a CVD risk factor, and vitamin $\mathrm{D}$ therapy and/or deficiency have been associated with CKD [129-137]. Similar associations have been made for heart failure [138], peripheral artery disease [138], and diabetes [95]. Although this review tried to present all relevant studies related to $\mathrm{BP}, \mathrm{CHD}$, and stroke, some studies may have been overlooked.

With these limitations in mind, current evidence suggests that calcium intake/levels seem (1) to decrease SBP, (2) not to be associated with CHD, and (3) to decrease the risk of stroke. Calcium supplementation seems (1) to reduce SBP among hypertensive patients, but not among normotensive people, and to have an inconsistent effect on DBP, and (2) to increase the risk of MI. Vitamin D intake/levels seem (1) to have inconsistent effects on BP and $\mathrm{CHD}$, and (2) to predict the risk of stroke. Vitamin D supplementation seems to decrease SBP and to have no effect on CHD or stroke.

CVD is a major cause of morbidity and mortality in the USA and worldwide [139], and BP, type 2 diabetes, 
dyslipidemia, and the metabolic syndrome are major CVD risk factors. Several mechanisms can support hypothetical associations between calcium or vitamin $\mathrm{D}$ and CVD and cardiovascular risk factors. The studies conducted so far have several limitations. In observational studies, causal relations cannot be established because of possible bias, confounding and reverse causation. In secondary analyses of RCTs, sample sizes are generally too small and dosage and follow-up inappropriate to study CVD outcomes.

Because there are still unexplained variations and several paradoxes in the pathogenesis of CVD [120], the quest to identify new predictors of CVD is ongoing. More than 160 studies have assessed the associations of calcium or vitamin D with CVD, but no RCT was primarily designed and conducted to investigate whether calcium or vitamin $\mathrm{D}$ supplementation is able to reduce cardiovascular risk factors and CVD mortality. Thus, new RCTs are clearly needed. Performing such a RCT will raise ethical (could one not supplement a patient with vitamin D deficiency and randomize to the placebo group?) as well as logistical and economic (e.g., will require a large sample and need to be conducted for a long time) issues, but 'if complexity is the price of being relevant and addressing the major public health problems, then so be it' [140].

\section{Acknowledgements}

I. Guessous is supported by a Swiss National Science Foundation grant (SNF 33CM30-124087/1). M. Bochud is supported by the Swiss School of Public Health Plus (SSPH+).

\section{References}

1 Allender PS, et al: Dietary calcium and blood pressure: a meta-analysis of randomized clinical trials. Ann Intern Med 1996;124: 825-831.

$\checkmark 2$ Bucher HC, et al: Effects of dietary calcium supplementation on blood pressure. A metaanalysis of randomized controlled trials. JAMA 1996;275:1016-1022.

-3 Cappuccio FP, Siani A, Strazzullo P: Oral calcium supplementation and blood pressure: an overview of randomized controlled trials. J Hypertens 1989;7:941-946.

4 Dickinson $\mathrm{HO}$, et al: Calcium supplementation for the management of primary hypertension in adults. Cochrane Database Syst Rev 2006;CD004639.

5 Griffith LE, et al: The influence of dietary and nondietary calcium supplementation on blood pressure: an updated meta-analysis of randomized controlled trials. Am J Hypertens 1999;12:84-92.

-6 Van Mierlo LA, et al: Blood pressure response to calcium supplementation: a metaanalysis of randomized controlled trials. J Hum Hypertens 2006;20:571-580.

7 Chung M, et al: Vitamin D and calcium: a systematic review of health outcomes. Evid Rep Technol Assess (Full Rep) 2009;183:1420.

$>8$ Miller GD, et al: Benefits of dairy product consumption on blood pressure in humans: a summary of the biomedical literature. J Am Coll Nutr 2000;19(suppl):147S-164S.

$\checkmark 9$ Alonso A, et al: Low-fat dairy consumption and reduced risk of hypertension: the Seguimiento Universidad de Navarra (SUN) cohort. Am J Clin Nutr 2005;82:972-979.
10 Ascherio A, et al: A prospective study of nutritional factors and hypertension among US men. Circulation 1992;86:1475-1484.

$>11$ Dwyer JH, et al: Dietary calcium, alcohol, and incidence of treated hypertension in the NHANES I epidemiologic follow-up study. Am J Epidemiol 1996;144:828-838.

$\checkmark 12$ Ford ES, Cooper RS: Risk factors for hypertension in a national cohort study. Hypertension 1991; 18:598-606.

13 Wang L, et al: Dietary intake of dairy products, calcium, and vitamin D and the risk of hypertension in middle-aged and older women. Hypertension 2008;51:1073-1079.

14 Ascherio A, et al: Prospective study of nutritional factors, blood pressure, and hypertension among US women. Hypertension 1996; 27:1065-1072.

15 Schatzkin A, et al: A comparison of a food frequency questionnaire with a 24-hour recall for use in an epidemiological cohort study: results from the biomarker-based $\mathrm{Ob}$ serving Protein and Energy Nutrition (OPEN) study. Int J Epidemiol 2003;32: 1054-1062.

$>16$ Bulpitt CJ, Hodes C, Everitt MG: The relationship between blood pressure and biochemical risk factors in a general population. Br J Prev Soc Med 1976;30:158-162.

17 Vargas CM, Obisesan T, Gillum RF: Association of serum albumin concentration, serum ionized calcium concentration, and blood pressure in the Third National Health and Nutrition Examination Survey. J Clin Epidemiol 1998;51:739-746.

18 Fogh-Andersen N, et al: Sex-dependent relation between ionized calcium in serum and blood pressure. Clin Chem 1984;30:116-118.
19 Buckley BM, et al: Lack of evidence of low ionized calcium levels in systemic hypertension. Am J Cardiol 1987;59:878-880.

20 Jorde R, et al: Serum calcium and cardiovascular risk factors and diseases: the Tromsø study. Hypertension 1999;34:484-490.

21 Lind L, et al: Relation of serum calcium concentration to metabolic risk factors for cardiovascular disease. BMJ 1988;297:960-963.

$>22$ Phillips AN, Shaper AG: Serum calcium and blood pressure. J Hum Hypertens 1991;5: 479-484.

23 Ogard CG, et al: Serum ionised calcium and cardiovascular disease in 45-year-old men and women followed for 18 years. Eur J Epidemiol 2006;21:123-127.

24 Jorde R, Bonaa KH, Sundsfjord J: Population-based study on serum ionised calcium, serum parathyroid hormone, and blood pressure. The Tromsø study. Eur J Endocrinol 1999; 141:350-357.

25 Kesteloot H, Joossens JV: Relationship of serum sodium, potassium, calcium, and phosphorus with blood pressure. Belgian Interuniversity Research on Nutrition and Health. Hypertension 1988;12:589-593.

26 Hunt SC, Williams RR, Kuida H: Different plasma ionized calcium correlations with blood pressure in high and low renin normotensive adults in Utah. Am J Hypertens 1991; 4:1-8.

27 McCarron DA: Low serum concentrations of ionized calcium in patients with hypertension. N Engl J Med 1982;307:226-228.

28 Resnick LM: The role of dietary calcium in hypertension: a hierarchical overview. Am J Hypertens 1999;12:99-112. 
29 Zemel MB: Calcium modulation of hypertension and obesity: mechanisms and implications. J Am Coll Nutr 2001;20(suppl):428S435S, 440S-442S.

30 Zemel MB: Nutritional and endocrine modulation of intracellular calcium: implications in obesity, insulin resistance and hypertension. Mol Cell Biochem 1998;188:129-136.

-31 Bohr DF: Vascular smooth muscle: dual effect of calcium. Science 1963;139:597-599.

- 32 Ledoux J, et al: Calcium-activated potassium channels and the regulation of vascular tone. Physiology (Bethesda) 2006;21:69-78.

- 33 Iwamoto T, et al: Salt-sensitive hypertension is triggered by $\mathrm{Ca}^{2+}$ entry via $\mathrm{Na}^{+} / \mathrm{Ca}^{2+}$ exchanger type-1 in vascular smooth muscle. Nat Med 2004;10:1193-1199.

34 Zulian A, et al: Up-regulation of $\mathrm{Na}^{+} / \mathrm{Ca}^{2+}$ exchanger and TRPC6 contributes to abnormal $\mathrm{Ca}^{2+}$ homeostasis in arterial smooth muscle cells from Milan hypertensive rats. Am J Physiol Heart Circ Physiol 2010; 299:H624-H633.

-35 Levy D, et al: Genome-wide association study of blood pressure and hypertension. Nat Genet 2009;41:677-687.

-36 Resnick LM, et al: Divalent cations in essential hypertension. Relations between serum ionized calcium, magnesium, and plasma renin activity. N Engl J Med 1983;309:888-891.

37 Touyz RM, Panz V, Milne FJ: Relations between magnesium, calcium, and plasma renin activity in black and white hypertensive patients. Miner Electrolyte Metab 1995;21: 417-422.

38 Maillard MP, et al: Calcium-sensing receptors modulate renin release in vivo and in vitro in the rat. J Hypertens 2009;27:19801987.

-39 Bolland MJ, et al: Vascular events in healthy older women receiving calcium supplementation: randomised controlled trial. BMJ 2008;336:262-266.

-40 Grant AM, et al: Oral vitamin $\mathrm{D}_{3}$ and calcium for secondary prevention of low-trauma fractures in elderly people (Randomised Evaluation of Calcium Or vitamin D, RECORD): a randomised placebo-controlled trial. Lancet 2005;365:1621-1628.

-41 Hsia J, et al: Calcium/vitamin D supplementation and cardiovascular events. Circulation 2007;115:846-854.

42 Prince RL, et al: Effects of calcium supplementation on clinical fracture and bone structure: results of a 5-year, double-blind, placebo-controlled trial in elderly women. Arch Intern Med 2006;166:869-875.

43 Bolland MJ, et al: Effect of calcium supplements on risk of myocardial infarction and cardiovascular events: meta-analysis. BMJ 2010;341:c3691.

44 Al-Delaimy WK, et al: A prospective study of calcium intake from diet and supplements and risk of ischemic heart disease among men. Am J Clin Nutr 2003;77:814-818.
45 Bostick RM, et al: Relation of calcium, vitamin $\mathrm{D}$, and dairy food intake to ischemic heart disease mortality among postmenopausal women. Am J Epidemiol 1999;149: 151-161.

46 Marniemi J, et al: Dietary and serum vitamins and minerals as predictors of myocardial infarction and stroke in elderly subjects. Nutr Metab Cardiovasc Dis 2005;15:188197.

47 Umesawa M, et al: Dietary intake of calcium in relation to mortality from cardiovascular disease: the JACC Study. Stroke 2006;37:20 26.

48 Umesawa M, et al: Dietary calcium intake and risks of stroke, its subtypes, and coronary heart disease in Japanese: the JPHC Study Cohort I. Stroke 2008;39:2449-2456.

49 Van der Vijver LP, et al: Calcium intake and 28-year cardiovascular and coronary heart disease mortality in Dutch civil servants. Int J Epidemiol 1992;21:36-39.

50 Palmer M, et al: Survival and renal function in untreated hypercalcemia: populationbased cohort study with 14 years of followup. Lancet 1987;1:59-62.

51 Leifsson BG, Ahren B: Serum calcium and survival in a large health screening program. J Clin Endocrinol Metab 1996;81:2149-2153.

52 Lind L, et al: Serum calcium: a new, independent, prospective risk factor for myocardial infarction in middle-aged men followed for 18 years. J Clin Epidemiol 1997;50:967-973.

53 Larsson SC, et al: Magnesium, calcium, potassium, and sodium intakes and risk of stroke in male smokers. Arch Intern Med 2008;168:459-465.

54 Carlson LA, et al: Effects of oral calcium upon serum cholesterol and triglycerides in patients with hyperlipidemia. Atherosclerosis 1971;14:391-400.

55 Karanja N, et al: Plasma lipids and hypertension: response to calcium supplementation. Am J Clin Nutr 1987;45:60-65.

56 De Bacquer D, et al: Epidemiological evidence for an association between serum calcium and serum lipids. Atherosclerosis 1994; 108:193-200.

57 Reid IR, et al: Effects of calcium supplementation on serum lipid concentrations in normal older women: a randomized controlled trial. Am J Med 2002;112:343-347.

58 Wareham NJ, et al: Glucose intolerance is associated with altered calcium homeostasis: a possible link between increased serum calcium concentration and cardiovascular disease mortality. Metabolism 1997;46:11711177.

59 Sun G, et al: Altered calcium homeostasis is correlated with abnormalities of fasting serum glucose, insulin resistance, and $\beta$-cell function in the Newfoundland population. Diabetes 2005;54:3336-3339.

60 Renaud S, et al: Platelet functions in relation to diet and serum lipids in British farmers. $\mathrm{Br}$ Heart J 1981;46:562-570.
61 Renaud S, et al: Nutrients, platelet function and composition in nine groups of French and British farmers. Atherosclerosis 1986; 60:37-48.

62 Larsson TE, et al: Conjoint effects of serum calcium and phosphate on risk of total, cardiovascular, and noncardiovascular mortality in the community. Arterioscler Thromb Vasc Biol 2010;30:333-339.

63 Tonelli M, et al: Relation between serum phosphate level and cardiovascular event rate in people with coronary disease. Circulation 2005; 112:2627-2633.

64 Detrano R, et al: Coronary calcium as a predictor of coronary events in four racial or ethnic groups. N Engl J Med 2008;358:13361345

65 Weintraub WS, Diamond GA: Predicting cardiovascular events with coronary calcium scoring. N Engl J Med 2008;358:13941396

-66 Manson JE, et al: Calcium/vitamin D supplementation and coronary artery calcification in the Women's Health Initiative. Menopause 2010;17:683-691.

67 Reid IR, Bolland MJ, Grey A: Does calcium supplementation increase cardiovascular risk? Clin Endocrinol (Oxf) 2010;73:689695 .

68 Ascherio A, et al: Intake of potassium, magnesium, calcium, and fiber and risk of stroke among US men. Circulation 1998;98:11981204

69 Iso H, et al: Prospective study of calcium, potassium, and magnesium intake and risk of stroke in women. Stroke 1999;30:1772-1779.

70 Ross RK, et al: Prospective evaluation of dietary and other predictors of fatal stroke in Shanghai, China. Circulation 1997;96:5055.

71 Weng LC, et al: Is ischemic stroke risk related to folate status or other nutrients correlated with folate intake? Stroke 2008;39:31523158.

72 Ovbiagele B, et al: Are elevated admission calcium levels associated with better outcomes after ischemic stroke? Neurology 2006;67:170-173.

73 Ovbiagele B, et al: Serum calcium as prognosticator in ischemic stroke. Stroke 2008; 39:2231-2236.

74 Peuler JD, Schelper RL: Partial protection from salt-induced stroke and mortality by high oral calcium in hypertensive rats. Stroke 1992;23:532-538.

75 Pfeifer M, et al: Effects of a short-term vitamin $D_{3}$ and calcium supplementation on blood pressure and parathyroid hormone levels in elderly women. J Clin Endocrinol Metab 2001;86:1633-1637.

76 Nagpal J, Pande JN, Bhartia A: A doubleblind, randomized, placebo-controlled trial of the short-term effect of vitamin $\mathrm{D}_{3}$ supplementation on insulin sensitivity in apparently healthy, middle-aged, centrally obese men. Diabet Med 2009;26:19-27. 
77 Scragg R, Khaw KT, Murphy S: Effect of winter oral vitamin $\mathrm{D}_{3}$ supplementation on cardiovascular risk factors in elderly adults. Eur J Clin Nutr 1995;49:640-646.

78 Krause R, et al: Ultraviolet B and blood pressure. Lancet 1998;352:709-710.

$\checkmark 79$ Joffres MR, Reed DM, Yano K: Relationship of magnesium intake and other dietary factors to blood pressure: the Honolulu heart study. Am J Clin Nutr 1987;45:469-475.

-80 Sowers MR, Wallace RB, Lemke JH: The association of intakes of vitamin D and calcium with blood pressure among women. Am J Clin Nutr 1985;42:135-142.

-81 Scragg R, Sowers M, Bell C: Serum 25-hydroxyvitamin $\mathrm{D}$, ethnicity, and blood pressure in the Third National Health and Nutrition Examination Survey. Am J Hypertens 2007;20:713-719.

82 Hypponen E, et al: 25-hydroxyvitamin D, IGF-1, and metabolic syndrome at 45 years of age: a cross-sectional study in the 1958 British Birth Cohort. Diabetes 2008;57:298-305.

83 Hintzpeter B, et al: Vitamin D status and health correlates among German adults. Eur J Clin Nutr 2008;62:1079-1089.

84 Snijder MB, et al: Vitamin D status and parathyroid hormone levels in relation to blood pressure: a population-based study in older men and women. J Intern Med 2007;261: 558-565.

-85 Scragg R, et al: Plasma 25-hydroxyvitamin $\mathrm{D}_{3}$ and its relation to physical activity and other heart disease risk factors in the general population. Ann Epidemiol 1992;2:697-703.

86 Scragg R, Khaw KT, Murphy S: Lifestyle factors associated with winter serum 25-hydroxyvitamin D levels in elderly adults. Age Ageing 1995;24:271-275.

87 Lind L, et al: Vitamin D is related to blood pressure and other cardiovascular risk factors in middle-aged men. Am J Hypertens 1995;8:894-901.

-88 Scragg R, et al: Serum 25-hydroxycholecalciferol concentration in newly detected hypertension. Am J Hypertens 1995;8:429432.

89 Rueda S, et al: Vitamin D, PTH, and the metabolic syndrome in severely obese subjects. Obes Surg 2008;18:151-154.

$>90$ Reis JP, et al: Vitamin D, parathyroid hormone levels, and the prevalence of metabolic syndrome in community-dwelling older adults. Diabetes Care 2007;30:1549-1555.

$\checkmark 91$ Argiles A: Blood pressure is correlated with vitamin $\mathrm{D}_{3}$ serum levels in dialysis patients. Blood Purif 2002;20:370-375.

$\checkmark 92$ Brickmann AS, et al: Calcitropic hormones, platelet calcium, and blood pressure in essential hypertension. Hypertension 1990;16: 515-522.

$\$ 93$ Kokot F, et al: Influence of ultraviolet irradiation on plasma vitamin $\mathrm{D}$ and calcitonin levels in humans. Kidney Int Suppl 1989; 27:S143-S146.
94 Muray S, et al: Influence of vitamin D receptor gene polymorphisms and 25-hydroxyvitamin D on blood pressure in apparently healthy subjects. J. Hypertens 2003;21:20692075 .

95 Forouhi NG, et al: Baseline serum 25-hydroxyvitamin D is predictive of future glycemic status and insulin resistance: the Medical Research Council Ely Prospective Study 1990-2000. Diabetes 2008;57:26192625.

96 Forman JP, et al: Plasma 25-hydroxyvitamin D levels and risk of incident hyperten sion. Hypertension 2007;49:1063-1069.

$\$ 97$ Forman JP, Curhan GC, Taylor EN: Plasma 25-hydroxyvitamin D levels and risk of incident hypertension among young women. Hypertension 2008;52:828-832.

-98 Jorde R, et al: Serum 25-hydroxyvitamin D levels are strongly related to systolic blood pressure but do not predict future hypertension. Hypertension 2010;55:792-798.

\$9 Jorde R, Svartberg J, Sundsfjord J: Serum parathyroid hormone as a predictor of increase in systolic blood pressure in men. J Hypertens 2005;23:1639-1644.

100 Xiang W, et al: Cardiac hypertrophy in vitamin D receptor knockout mice: role of the systemic and cardiac renin-angiotensin systems. Am J Physiol Endocrinol Metab 2005;288:E125-E132.

101 Kong J, et al: Targeted vitamin D receptor expression in juxtaglomerular cells suppresses renin expression independent of parathyroid hormone and calcium. Kidney Int 2008;74:1577-1581.

102 Bonizzi G, Karin M: The two NF- $\kappa$ B activation pathways and their role in innate and adaptive immunity. Trends Immunol 2004; 25:280-288.

103 Guijarro C, Egido J: Transcription factor$\kappa \mathrm{B}(\mathrm{NF}-\kappa \mathrm{B})$ and renal disease. Kidney Int 2001;59:415-424.

104 Pilz S, et al: Vitamin D status and arterial hypertension: a systematic review. Nat Rev Cardiol 2009;6:621-630.

105 Wong MS, et al: Vitamin D derivatives acutely reduce endothelium-dependent contractions in the aorta of the spontaneously hypertensive rat. Am J Physiol Heart Circ Physiol 2008;295:H289-H296.

106 Talmor Y, et al: Calcitriol blunts the deleterious impact of advanced glycation end products on endothelial cells. Am J Physiol Renal Physiol 2008;294:F1059-F1064.

107 Richart T, Li Y, Staessen JA: Renal versus extrarenal activation of vitamin $\mathrm{D}$ in relation to atherosclerosis, arterial stiffening, and hypertension. Am J Hypertens 2007 20:1007-1015.

108 Grimes DS, Hindle E, Dyer T: Sunlight, cholesterol and coronary heart disease. QJM 1996;89:579-589.

109 Douglas AS, et al: Seasonal variation in coronary heart disease in Scotland. J Epidemiol Community Health 1995;49:575-582.
110 Trivedi DP, Doll R, Khaw KT: Effect of four monthly oral vitamin $\mathrm{D}_{3}$ (cholecalciferol) supplementation on fractures and mortality in men and women living in the community: randomised double-blind controlled trial. BMJ 2003;326:469.

111 LaCroix AZ, et al: Calcium plus vitamin D supplementation and mortality in postmenopausal women: the Women's Health Initiative calcium-vitamin $\mathrm{D}$ randomized controlled trial. J Gerontol A Biol Sci Med Sci 2009;64:559-567.

112 Wang TJ, et al: Vitamin D deficiency and risk of cardiovascular disease. Circulation 2008; 117:503-511

113 Dobnig $\mathrm{H}$, et al: Independent association of low serum 25-hydroxyvitamin $\mathrm{D}$ and 1,25-dihydroxyvitamin D levels with allcause and cardiovascular mortality. Arch Intern Med 2008;168:1340-1349.

114 Kendrick J, et al: 25-Hydroxyvitamin D deficiency is independently associated with cardiovascular disease in the third national health and nutrition examination survey. Atherosclerosis 2009;205:255-260.

115 Melamed ML, et al: 25-Hydroxyvitamin D levels and the risk of mortality in the general population. Arch Intern Med 2008;168: 1629-1637.

116 Kim DH, et al: Prevalence of hypovitaminosis D in cardiovascular diseases (from the National Health and Nutrition Examination Survey 2001 to 2004). Am J Cardiol 2008;102:1540-1544.

117 Rajasree S, et al: Serum 25-hydroxyvitamin $\mathrm{D}_{3}$ levels are elevated in South Indian patients with ischemic heart disease. Eur J Epidemiol 2001;17:567-571.

118 Scragg R, et al: Myocardial infarction is inversely associated with plasma 25-hydroxyvitamin $\mathrm{D}_{3}$ levels: a communitybased study. Int J Epidemiol 1990;19:559563.

119 Giovannucci E, et al: 25-Hydroxyvitamin $\mathrm{D}$ and risk of myocardial infarction in men: a prospective study. Arch Intern Med 2008; 168:1174-1180.

120 Zittermann A, Schleithoff SS, Koerfer R: Putting cardiovascular disease and vitamin $\mathrm{D}$ insufficiency into perspective. Br J Nutr 2005;94:483-492.

121 Rashid G, et al: Parathyroid hormone stimulates the endothelial expression of vascular endothelial growth factor. Eur J Clin Invest 2008;38:798-803.

122 Judd SE, Tangpricha V: Vitamin D deficiency and risk for cardiovascular disease. Am J Med Sci 2009;338:40-44.

123 O'Connell TD, et al: 1,25-Dihydroxyvitamin $\mathrm{D}_{3}$ regulation of cardiac myocyte proliferation and hypertrophy. Am J Physiol 1997;272:H1751-H1758.

124 Watson KE, et al: Active serum vitamin D levels are inversely correlated with coronary calcification. Circulation 1997;96: 1755-1760. 
125 Penckofer S, et al: Vitamin D and diabetes: let the sunshine in. Diabetes Educ 2008;34: 939-940, 942, 944 passim.

126 Pittas AG, et al: The role of vitamin D and calcium in type 2 diabetes. A systematic review and meta-analysis. J Clin Endocrinol Metab 2007;92:2017-2029.

- 127 Poole KE, et al: Reduced vitamin D in acute stroke. Stroke 2006;37:243-245.

$\checkmark 128$ Pilz S, et al: Low vitamin D levels predict stroke in patients referred to coronary angiography. Stroke 2008;39:2611-2613.

129 Teng M, et al: Survival of patients undergoing hemodialysis with paricalcitol or calcitriol therapy. N Engl J Med 2003;349: 446-456.

130 Teng M, et al: Activated injectable vitamin $\mathrm{D}$ and hemodialysis survival: a historical cohort study. J Am Soc Nephrol 2005;16: 1115-1125.
131 Kalantar-Zadeh K, et al: Survival predictability of time-varying indicators of bone disease in maintenance hemodialysis patients. Kidney Int 2006;70:771-780.

132 Tentori F, et al: Mortality risk among hemodialysis patients receiving different vitamin $\mathrm{D}$ analogs. Kidney Int 2006;70:1858-1865.

133 Palmer SC, et al: Meta-analysis: vitamin D compounds in chronic kidney disease. Ann Intern Med 2007;147:840-853.

$>134$ Agarwal R, et al: Antiproteinuric effect of oral paricalcitol in chronic kidney disease. Kidney Int 2005;68:2823-2828.

135 Alborzi P, et al: Paricalcitol reduces albuminuria and inflammation in chronic kidney disease: a randomized double-blind pilot trial. Hypertension 2008;52:249-255.

136 Fishbane S, et al: Oral paricalcitol in the treatment of patients with CKD and proteinuria: a randomized trial. Am J Kidney Dis 2009;54:647-652.
137 Melamed ML, et al: 25-hydroxyvitamin D levels, race, and the progression of kidney disease. J Am Soc Nephrol 2009;20:26312639.

138 Zittermann A, et al: Low vitamin D status: a contributing factor in the pathogenesis of congestive heart failure? J Am Coll Cardiol 2003;41:105-112.

139 Cooper R, et al: Trends and disparities in coronary heart disease, stroke, and other cardiovascular diseases in the United States: findings of the national conference on cardiovascular disease prevention. Circulation 2000;102:3137-3147.

140 Pearce N: Commentary: The rise and rise of corporate epidemiology and the narrowing of epidemiology's vision. Int J Epidemiol 2007;36:713-717. 